\title{
From Monthly Bulletins to eLaestadianism? Exploring Attitudes and Use of Internet within the Laestadian Movement
}

\author{
BENGT-OVE ANDREASSEN \\ University of Tromsø
}

\begin{abstract}
The different groups within the Laestadian movement have developed different strategies when it comes to internet and production of texts. Regarding internet and official websites, there is ambivalence towards the opportunities which this technology and new media offer. Among the approximately twenty different Laestadian groups which exist in the Nordic countries and America, there are only nine official websites in 2012. The article provides an overview over these websites, contents and strategies. Websites are discussed in reference to a well-established tradition of monthly bulletins within the Laestadian tradition. The term netnography is used to describe the research on religion and internet, and research ethics are also discussed as a part of doing research on religion and internet.
\end{abstract}

Keywords: Laestadian movement, internet research, eLaestadianism, netnography, research ethics

Websites established and run by Laestadian groups are a relatively new phenomenon within the Laestadian movement. In late 2009, as a first step towards establishing an overview of official Laestadian websites, I contacted scholars in theology, church history and religious studies who have done research on this movement. Rather surprisingly, the websites of Laestadian groups appeared to be little known, and not as yet explored in research. It therefore seemed relevant to present an overview of which Laestadian groups currently have official websites. In investigating how the different groups use the internet and what their attitudes towards internet are, I detected a range of different strategies, and ambivalence towards the 'new' media and technology. This article therefore pursues a descriptive purpose in providing an overview over existing official Laestadian websites and discussion of how Laestadian groups are using the websites.

It quickly became clear that the content on the websites needed to be seen in relation to the production of other texts within the Laestadian groups. 
The tradition of monthly bulletins within the Laestadian movement serves as an example of the group's attitude towards texts and the production of texts. Monthly bulletins have therefore been included in the article as a point of reference in examining attitudes towards the internet, as Heidi Campbell $(2010,21)$ has suggested. The traditions and teachings within different religious communities on how texts should be interpreted, handled, and performed must be recognized as forming the basis for communication practices, argues Campbell. Religious groups often hold deeply embedded rules as to how texts and media should be treated and understood, arising from their shared beliefs. Some Laestadian groups produce a wide range of text, and have websites which are frequently updated and used. Other groups, especially the Firstborn group in Norway and Sweden, produce varieties of texts, but have neither monthly bulletins nor websites. The data used for this article thus illustrate Campbell's argument about the relation between a religious group's attitudes to text in general and their attitudes to the internet.

The first part of the article will provide some background on the Laestadian movement, with special focus on the different communication strategies among its different subgroupings. Special emphasis will be put on the monthly bulletins, reflecting the pattern that those groups which publish monthly bulletins are the ones who have been most eager to use the internet. The second part provides an overview of the nine official websites run by Laestadian groups, and aims at mapping typologies and trends of how Laestadian groups online might reshape the religious community. The third part of the article discusses the question of whether websites are influencing the activities in the offline community.

\section{The Laestadian Movement}

The Laestadian movement has, since it arose in the mid and late 1800s, developed to be the largest Christian revival movement in Scandinavia. Today, however, the term 'the Laestadian movement' in the singular is highly questionable. The core reference is to a conservative evangelical Christian movement with its historical background in a revival in Northern Scandinavia in the environment round the Swedish minister Lars Levi Læstadius (1800-1861). All Laestadian groups today refer to this common heritage and view themselves as the true followers of Læstadius and his legacy.

By the end of the 19th century the Laestadian movement was an influential transnational religious movement across northern Scandinavia. 
When Læstadius' successor as leader, Johan Raattamaa (1811-1899), died, disputes arose regarding leadership and teachings and the movement was divided in two major traditions: Western and Eastern. Negotiating what the true legacy of Læstadius and true Christendom really is, the movement underwent during 20th century a series of schisms both within the Nordic countries and in the American diaspora (e.g. Hepokoski 2000; Talonen 2001a; Olsen 2008). In 2001 the Finnish church historian Jouko Talonen (2001a, 53) counted as many as eighteen separate Laestadian groups. With different official names, and divergent theological orientations, the various groups have developed very differently in different contexts. Most of the groups are trans-national, whilst others only exist in specific national contexts. In Finland, the different groups have remained more closely associated with the Evangelical-Lutheran Church compared to the groups in Norway and Sweden. In Norway and Sweden, for example, the 'Firstborn' groups have taken up positions in relatively clear opposition to the national churches, and have developed their own rituals for baptism and confirmation (cf. Nordvik 2013), whereas in Finland, the Firstborn have been reluctant to do so. The Firstborn group is still regarded as a single transnational group, but it has developed in noticeably different ways in the different national contexts. The website of the Finnish Firstborn provides an example on the tension within this group, as there are no official Firstborn websites in Norway, Sweden or America.

The relevance of these schisms to this study arises primarily because each group has tended to use its monthly bulletins or booklets to distance itself from other Laestadian groups (and other religious groups more generally), and to establish a group identity of their own. The official communication of a group's identity gives authority to its preachers and to their specific understanding of 'true Christianity'.

Several of these groups will be specifically referred to in this article as media producers. The Firstborn (with the Old Apostolic Lutheran Church of America as their American sister organization) form one of the main groupings within the wider Laestadian movement, and are synonymous with what is referred to as the Western tradition. All other groups have their background within the Eastern tradition, such as the Old Laestadians, in Finland named SRK (linked with the Laestadian Lutheran Church of America). The Small Firstborn (in Norwegian småførstefødte and in Finnish pikkuesikoiset), were established as a separate group after a schism within the Old Laestadians in Finland; they are officially labelled the Word of Peace Mission (Lähetysyhdistys Rauhan Sana) after their monthly bulletin with the same name. In northern 
Finland and Sweden, autonomous Swedish-speaking congregations in the Small Firstborn tradition have been united under the umbrella organisation Laestadianernas fridsföreningars förbund r.f. (LFF), also referred to in Swedish as the Tornedal Wing, and in Norway as the Alta Group, after their geographical location along the Torne and Alta rivers. The American sister group is the Apostolic Lutheran Church of America. In the early 1960s a schism within the SRK in Finland gave birth to the group Elämän sana [Word of Life]. This group is also called 'pappislinja' in Finnish ('the Clergy Branch' in English) as it was established by a group of ministers after a doctrinal dispute. It is regarded as a very small group within the Laestadian tradition. The LutheranLaestadian Congregation (Norwegian official name: Den luthersk-læstadianske menighet), often referred to as the Lyngen Group, exists only in Norway. The Reawakening (Finnish official name: Lestadiolainen uusherätys ry), is primarily a Finnish group with only very few adherents in Norway and Sweden.

In addition to these major groupings, a number of smaller subgroups also exist. Groups which don't have an official website are not included in this article. A more detailed overview of the full range of Laestadian groups can be found in Talonen (2001a; 2005, 195ff) and Hepokoski (2000). Despite the common heritage shared by all the different Laestadian groups, there are very significant differences in their attitudes and doctrinal emphases.

The transition from an industrial to an information society has created a major challenge for Christian conservative movements like the Laestadians, for whom modernism, in general, and especially the information society, has mainly been associated with 'the world' and consequently seen as a potential arena for 'the work of the Devil'. Nonetheless, as is typical of many Protestant movements, some groups within the Laestadian tradition have adopted the use of technological advances and developed a range of communication strategies. Since the late 1800s, collections of sermons and letters, historical books and booklets and monthly bulletins have been published in several languages, and widely distributed (see Andreassen 2011). Monthly bulletins in particular are a widely used as an appropriate and effective medium of self-communication - a tradition which was started with Læstadius himself with his bulletin The Voice of One Crying in the Wilderness, published in 1852-1854 (see Anderzèn 2009). Bulletins also form an effective communication strategy in the context of the enormous geographical distances in circumpolar Scandinavia. Because of these distances, with a very limited infrastructure, Laestadians could not travel frequently to attend gatherings. Monthly bulletins were intended to serve as a comfort and a reminder of the Christian faith in 'a world of sin', at times when longer 
journeys to attend gatherings were not possible. Consequently, it might be expected that internet technology would be regarded as an valuable tool for communication; but although this is true for some groups, nonetheless an ambivalence can still be detected towards this new technology.

\section{Theoretical Perspectives}

Since the 1990s, considerable attention has been paid to mediation as constituting a range of religious practices in different cultural settings and historical periods. This approach rests on a conceptualization of religion as a cultural phenomenon and a social construction (cf. Mack 2000). As a social construction, religion has a need to be mediated and communicated (Stolow 2005). This predicates a form of mediation that does not isolate belief, but articulates it within the context of social processes such as consumption, cohort formation, political resistance, transnationalism, postcolonial nationalism, and globalization (Morgan 2008, 8).

The theoretical perspectives applied in this article are not restricted to religion and the internet, but also reference perspectives which address a wide range of religious communication strategies among religious groups in general. The term 'communication strategies' addresses cultural media and practices, such as the internet, which communicate opinions, ideology, beliefs and values, which are thus generated, circulated, understood and acted upon (as in Hoover 2005; 2006; Hoover \& Emerich 2011; Hofmeyer 2008; Hosseini 2008; Stolow 2005). The websites and monthly bulletins which form the empirical basis for this article thus represent only a limited sample of a much wider range of communications techniques which have been addressed in recent religion and media research.

In addition to these general perspectives on religion and religious communication, I have used some more specific theoretical concepts developed within research on religion and on the internet, to map or characterise the development of Laestadian websites. In brief, these theoretical concepts are Helland's (2000; 2005) distinction between religion-online and onlinereligion, and Karaflogka's (2006) outline of e-religion.

\section{Approaching the Laestadian Movement Online: Netnography}

The topic of religion on the internet emerged as a relevant research approach in religious studies in the 1990s. In 2000, Lorne Dawson raised some basic questions for such research. He wrote: 
First, we need to know what is on the Internet, who has put it there, and for what purpose. Second, we need to know how many people are using these resources. How often are they using them? In what ways are they using them? We need to develop a social profile of those who use the internet for religious purposes. [...] Third, we need to know what influences these activities are having on religions and practices of users. (Dawson 2000, 28.)

Since 2000 the research on religion on the internet has developed and is now a vast field. However, Dawson's basic questions are still relevant, as is confirmed in Cowan's (2011) article on research on the internet eleven years later. Dawson's questions are of a fundamental nature, and are likely to continue to be so in face of the constant and rapid development of the internet and other social media.

It has been argued by a number of scholars in the social sciences that the internet is a social space, not just a technical opportunity (Kozinets 2010; Markham 2004). In the words of Anastasia Karaflogka (2006, 142), the internet 'is now regarded as an environment, which has the capacity to initiate new forms of interaction and new types of relations of power between participators'. New forms of technology should not be seen merely as aids to human activity, but also as influential forces acting to reshape social activity and its meaning (cf. Campbell 2011; Højsgaard \& Warburg 2005). The way in which the internet is perceived and understood also influences the process of choosing an appropriate research methodological approach.

Douglas E. Cowan (2011) has described four steps of analysis when approaching religions on the internet. Focus is put here mainly on areas relating to the first two steps: establishing an overview of existing official Laestadian websites, and describing their content; and secondly, investigating who is responsible for the content and for whom it is intended.

Cowan emphasizes that internet research must address both how content providers intend the material to be used, and how it is actually used by consumers. This question also relates to whether and how a religious group's online activity is affecting their offline activity. The prime reason for focusing here on Cowan's first two steps is that different Laestadian groups are found to make use of the internet to a varied extent and in different ways. It is argued that these differences depend on how the different groups relate to text more generally. Cowan's step three and four would only be possible to do in a study which studies one particular website in depth. The broad perspective adopted in this article, covering the websites 
of all Laestadian groups, therefore has its limitations regarding depth, which must be left for future research.

The research approach in this article has also been inspired by the concept netnography as developed by Robert Kozinets $(2010,60)$. Based on anthropological research and ethnography, Kozinets defines netnography as participant-observational research based on online fieldwork. The primary research data consists of computer-mediated communications, but other source material might include interviews, descriptive statistics, archive data, etc. Website construction and activities are seen in relation to and compared with the more traditional communication strategies among the different Laestadian groups: above all, the monthly bulletin.

In order to get an overview over existing official Laestadian websites, one cannot solely rely on search engines and directories such as Google, Sol or Wikipedia (cf. Cowan 2011, 463-4). A search on key words like 'laestadian' and/or 'website' or 'homepage' (in English, Norwegian, Swedish and Finnish) provided not only a wide range of hits about the Laestadian movement in general, but also hits to Laestadian websites in English and various local subgroups of the Laestadian Lutheran church in America. Other hits included 'Learning to live free', an American website for people who have left a Laestadian congregation, especially the Old Apostolic Lutheran Church of America (Firstborns), and was established because of an 'obligation to tell the truth' about the congregation: stories of abuse of power, violence and suppression. Such sites constitute an interesting but distinct genre, and I will not discuss this website any further in this article.

One reason why search engines provide few direct hits to official Laestadian websites is that many Laestadian groups do not use the word 'Laestadian' either in their official name as a denomination or in the name of the website. Laestadians today primarily label themselves as 'Christians'; and since the official names of the different Laestadian congregations include words like Christian, Lutheran, Apostolic or Evangelical, relying on search engines to locate Laestadian websites is unreliable. Christian groups have moreover been very active on the internet, which means that using basic or traditional Christian terms in a search engine will provide millions of hits (cf. Campbell 2010; Laney 2005). However, a search using the official name of one of the Laestadian groups will usually list the official website among the top five hits. A search on 'Suomen Rauhanyhdistysten Keskusyhdistys (SRK)' provided a direct hit to the Finnish website of SRK. The same applied for a search on the Norwegian words 'luthersk' and 'laestadiansk', which gave a direct hit to the Norwegian Lyngen group's website. The 
Finnish 'esikoislestadiolaisuus' gave a direct hit to the website of the Finnish Firstborn group. Hence, it is important to know the exact name or internet address of the specific group for effective internet access.

In addition to search engines, I used informants within different Laestadian groups and contacted scholars in Nordic countries. I also tried to use monthly bulletins as a source of information of websites, but the bulletins rarely include references to the websites (whereas the website frequently refer to the monthly bulletins). The Lyngen group's website, for example, was launched in 2003, yet no reference to this website was made in the group's monthly bulletin Under vandringen until 2011. In contrast, the LFF bulletin Sions missionstidning does provide detailed information about the organization's website. Having established a list of the major Laestadian websites, I then monitored them over a period of up to four years through participant observation as online fieldwork.

\section{Research Ethics}

Netnographic online fieldwork and observation, like any other fieldwork, generates questions of research ethics. In fieldwork with direct contact with research subjects, the researcher is under obligation to inform them about one's presence, and to secure disclosure and informed consent (Cowan 2011, 468; Bird \& Lamoureux Scholes 2011). Should online fieldwork be under the same obligation? One could argue that website access does involve a kind of interaction with subjects, and thus require informed consent. In my research on the Laestadian websites, this has been a difficult ethical question, and I am aware that my choices and arguments as to what is ethically prudent might be questioned.

I decided not to inform the subjects about my presence or to collect informed consent. The main justification for not considering this as necessary is that I was visiting official websites which are publicly available, and whose primary purpose is to spread general information. I have done my observation by surfing the internet. The research ethics become more complex in dealing with discussion forums, especially the Finnish Rauhan Sana website. Again, my justification is that these are publicly accessible; moreover, the persons who were active in these discussion forums use nicknames, which make it impossible to identify them (for an outsider). However, despite the fact that statements and comments on public discussion forums are anonymous, I do recognise these forums as muddy waters for the researcher. In my discussion, therefore, I do refer to these forums, 
and have given examples on issues that are discussed, but I have not used these discussions as material for a comprehensive analysis. On the Lyngen Group's website, a log-in ID was required to enter the discussion forum, and I chose not to register. The discussion rooms are obviously very interesting from a research perspective, as they would provide information about current topics among young Laestadians, but if the discussion forum required log-in access, I took this as a sign that this room was closed to the public and participation from an outsider would be unwelcome. The research practices followed here have thus been restricted to what can be accessed by any person surfing the internet, which I regard as ethically sustainable since this research project follows a general overall perspective, and does not discuss or identify single persons.

\section{Laestadian Communication Strategies - From Monthly Bulletins to Websites}

The Laestadian movement is a typical Protestant Lutheran-Evangelical movement. The spoken word is important, as it is seen as the living word of God. The Laestadians gather in weekly assemblies to hear the spoken word, and both in summer and winter, meetings are held for people from different regions and countries to meet. As mentioned above, the distances and infrastructure in the circumpolar region make it difficult not only for people to travel to attend gatherings, but also for preachers to travel in these areas. To reach people across this vast geographical area, the need for religious literature and readings soon emerged. Technological advances made it possible to print bulletins at a reasonable price. Distribution was by mail, and as the number of followers grew, it generated the economic basis for printing and distribution. The practice of publishing monthly bulletins is nothing specific to the Laestadian movement compared to other Protestant Christian groups; it rather confirms Laestadianism as a typical example of the EvangelicalProtestant movements, which have been described as a 'medium of mass communication' in the nineteenth century, with reference to their production and distribution of transnational printed texts (Hofmeyer 2008, 200-1).

The main era for monthly bulletins began about twenty years after Læstadius' death. A survey of Laestadian bulletins by the Finnish church historian Pekka Raittila in 1967 identified thirty-two Laestadian monthly bulletins published during the period 1880-1967 (Raittila 1967, 320-4). The earliest one listed in Raittila's list was Kristillinen kuukauslehti, established in Oulu in 1880. During the 1880s and 1890s, five more bulletins were launched, 
all but one in Finland (the exception being in America). In the early 1900s, more bulletins saw the light of day, but appear to have been published for limited geographical areas and periods. Only a few of these still exist in 2012, but in the meantime, others have been launched.

Laestadian monthly bulletins are an important medium of self-representation for the different groups: not merely as delivery devices, but also for the generation of shared experiences and consciousness and community, that allows Laestadians to assemble meanings that articulate and extend their relations to one another (cf. Morgan 2008, 7). Monthly bulletins can display cognitive and aesthetic patterns which help to construct and maintain definitive boundaries which are characteristic of many Christian revival movements, such as inside and outside, us and them, centre and periphery, old and new. These structures construct fundamental aspects of social identity by mapping out the temporal, spatial and imagined terrains of each Laestadian group. The bulletins are each Laestadian group's 'plausible narrative of their self', to use a phrase by Hoover $(2006,264)$, and thus an important identity marker. These bulletins are always, without exception, closely connected to a specific Laestadian group, or even to a local or regional fraction of a group. For instance, the editor of the Finnish Firstborn's bulletin Rauhan Side informed me that the bulletin had a total of 3,387 subscribers in 2009. Of these, 223 were in other countries, including Sweden (80), Norway (40) and America (41). For a transnational group like the Firstborn, and taking into account that this is the only current written bulletin distributed within this group, one might have expected a wider distribution. The main reason for the limited distribution outside Finland is of course language, since the bulletin is published in Finnish. It also says something about how the movement has developed, since Finnish was regarded as a lingua sacra within the movement in the late 1800s. On a general basis, one can say that monthly bulletins provide a channel to communicate each group's beliefs, and at the same time draw borders in relation to other groups, through their own exclusive and exclusivist interpretation of the heritage from Læstadius and the Laestadian tradition.

Bulletins are also historical texts, and thus represent a well-known source category in historically-oriented research on religion. However, new theoretical insights from research on religion and media can also be applied on such texts, opening up new aspects and insights within the Laestadian movement. As Campbell $(2010,21)$ argues, a community's historical approach to texts can provide important indicators of how they will approach and decipher new media, such as the internet. 
A distinction is often made in media research between 'push' and 'pull' factors (Hoover 2008, 32-3). 'Push' describes media which carry information and messages that are intended to motivate behaviour directly. From this perspective, the written bulletin might be seen as reflecting a more passive and perhaps reactive audience, in comparison to more recent digital media (ibid., 32). The Laestadian written bulletins are a classic instantiation of 'push' media, always intended to serve some common purpose: to transmit greetings to each individual member, in rural areas separated from fellow members by long distances, and to supply each member with the preaching and views of that specific Laestadian tradition. The bulletins also serve as a reminder and reinforcement of what has been preached at the group's gatherings. 'Pull' media, on the other hand, ascribe more control to the users - they can 'pull' out what they want. The digital media are prominent examples of 'pull' media, constituting a context or supply of resources for audiences to select from.

\section{Laestadian Websites}

The provision of websites by Laestadian groups is, for the time being, rather limited. Not all groups have a website at all, while some groups, such as the LFF, maintain separate websites for their various local congregations. However, it is to be expected that more websites will be established in the years to come.

I have traced nine official websites, ${ }^{1}$ which is still quite a low number when one takes into account that there are about twenty distinct Laestadian groups, and the large number of monthly bulletins and other texts that they publish. The official websites existing in the first half of 2012 are:

\begin{tabular}{|l|l|}
\hline Laestadian group & Website \\
\hline $\begin{array}{l}\text { Laestadianernas fridsföreningars } \\
\text { förbund r.f. (LFF) }\end{array}$ & $\begin{array}{l}\text { http://www.lff.fi } \\
\text { (website in Swedish) }\end{array}$ \\
\hline Rauhan Sana group & $\begin{array}{l}\text { http://www.lyrs.fi/ } \\
\text { (website in Finnish) }\end{array}$ \\
\hline
\end{tabular}

1 This is not to seen as complete overview of every Laestadian site or source on the internet (cf. Cowan 2011, 465-6). My count only includes the main LFF website; I have not included the numerous websites of local LFF congregations in Finland and Sweden, or the websites of local congregations of the Laestadian Lutheran Church in America. 


\begin{tabular}{|l|l|}
\hline Laestadian group & Website \\
\hline $\begin{array}{l}\text { Apostolic Lutheran Church of } \\
\text { America }\end{array}$ & $\begin{array}{l}\text { http://www.apostoliclutheran.org } \\
\text { (website in English) }\end{array}$ \\
\hline $\begin{array}{l}\text { Suomen Rauhanyhdistysten Kes- } \\
\text { kusyhdistys (SRK) }\end{array}$ & $\begin{array}{l}\text { http://www.srk.fi } \\
\text { (website in Finnish) }\end{array}$ \\
\hline Elämän sana & $\begin{array}{l}\text { www.elamansana.fi } \\
\text { (website in Finnish) }\end{array}$ \\
\hline Laestadian Lutheran Church (LCC) & $\begin{array}{l}\text { http://www.llchurch.org } \\
\text { (website in English) }\end{array}$ \\
\hline Lyngen group & $\begin{array}{l}\text { www.samlinga.net } \\
\text { (website in Norwegian) }\end{array}$ \\
\hline Firstborn group (in Finland) & $\begin{array}{l}\text { http://www.esikoislestadiolainen.fi } \\
\text { (website in Finnish) }\end{array}$ \\
\hline $\begin{array}{l}\text { The Reawakening (Lestadiolainen } \\
\text { Uusheräys ry) }\end{array}$ & $\begin{array}{l}\text { http://www.uusherays.fi } \\
\text { (website in Finnish) }\end{array}$ \\
\hline
\end{tabular}

These websites serve first and foremost as tools for spreading information about meetings, how to get devotional literature, the 'outer and inner mission', and information about subscription to bulletins. The LFF, Rauhan Sana, SRK, Elämän sana and Finnish Firstborn websites also offer radio podcasts and/or live streaming of worship services, as do all the American websites. The website of Elämän sana is the only group which offers both radio and TV streaming. The Finnish Firstborns is the only website which publicly records the number of hits (over 65, 000 visitors in 20112, about 63, 000 of which were from within Finland).

The websites of The Reawakening and the Firstborns in Finland are exclusively in Finnish, and similarly the Lyngen group's is exclusively in Norwegian. The Lyngen group's website is also the only one which explicitly addresses youth work. In addition to an official introduction to the group, it provides a calendar and syllabus for the youth work. It is also the only website with lots of pictures from various youth activities.

An interesting pattern is that the majority of websites in the Nordic countries are established and run by Finnish groups. At this point it is difficult to explain why it is so. One might argue that it is a coincidence that the websites are run from Finland. If one were to accept such an argument, one could expect these websites to be in multiple languages - Swedish,

2 http://www.esikoislestadiolainen.fi/uutiset.html (last visited 1st March 2012). 
Norwegian and English - and not just in Finnish; but that is not the case. These websites are primarily in one language, and other languages are available only to a limited extent. Sermons available in podcast or streaming are, however, often translated from Finnish to Swedish (or vice versa), which is a common practice at Laestadian gatherings. Another possible explanation could be that the Laestadian groups in Finland and America have, in general, been more oriented towards missionary work than the groups in Sweden and Norway. The Finnish groups are in this sense more directed towards activities external to the group. However, although the Finnish groups' policies prioritize outer mission in the Baltic countries and Russia, the websites have no content in these languages. The American websites are also more focused on outer/foreign mission. An example is the Apostolic Lutheran Church of America's website, which has a link to the group's separate website for foreign mission (www.themissionsite.com), providing information about the group's mission work which closely corresponds to that in the quarterly bulletin Where He Leads.

In Sweden and Norway, on the other hand, the priority has been placed more on inner mission and working within local and regional congregations. Consequently, in addition to general information about each group on the homepage, these websites are mostly directed towards an audience of insiders. This national or regional orientation of the websites, illustrated by the number of hits reported on the Firstborn's website as mentioned above, seems to be in contradiction to descriptions of the Laestadian movement as transnational. This is rather surprising, in particular with reference to the large gatherings during the summer (and to some extent in the winter) which attract Laestadians from all the Nordic countries.

There seems to be a clear connection between the use of websites and publishing monthly bulletins. ${ }^{3}$ There is a distinct pattern that all groups which have established a website also have well-established monthly bulletins. Of the website groups listed here, all publish a monthly bulletin (or other periodicals). On the other hand, the Swedish and Norwegian Firstborns maintain neither a bulletin nor a website; these groups have in fact almost no tradition of publishing monthly bulletins. The only known monthly bulletin is Faderrösten (also translated and published in English as The Father's Voice), which came out from 1960 to 1989 (see Andreassen 2011). It is therefore striking that the Finnish Firstborn group publish both a monthly bulletin and a website, whereas in Norway or Sweden there is

3 The bulletin of Elämän sana (with the identical name as the group) was published up to the end of 2000 (Talonen 2001b, 42-3). 
neither bulletin nor website. The Finnish Firstborn group thus seem to be behaving relatively autonomously, and to be directed towards their national context in Finland. This pattern is particularly interesting in relation to the authority of 'the Elders' and the 'Mother Congregation' in Swedish Lapland, which are of great importance in the Firstborn tradition, and the Finnish Firstborn's website and monthly bulletin seem to confirm an underlying tension between the Finnish Firstborns and their origins in Swedish Lapland (cf. Andreassen 2011; Hokka 2006).

\section{Website Contents}

The content of the websites corresponds fairly close with that of the bulletins for each group. The radio streaming and podcasts on the SRK and LFF websites are more or less a live version of the bulletin, which largely consist of excerpts from sermons and devotional literature, supplemented by information about gatherings and mission trips. However, the websites are not merely electronic versions of the bulletins. Despite their additional content and functions, nonetheless, the layout and the high proportion of devotional content on the websites indicate an intended 'push' function, and an effort to reduce the possibility of an eclectic 'pull' function. In some ways the websites serve a very similar purpose to the bulletins. A prime function seems to be to repeat and reinforce sermons and what has been said at the group's gatherings. Thus, to (re)publish what is already known seems to some extent to be the main purpose both through the bulletins, and on the websites in either text or streaming services.

A major difference between websites and bulletins is of course that websites have more space, and thus more opportunity for each group to present themselves. It also provides opportunities to issue official statements. One example was a statement on the LFF website in January 2010 concerning a case where an LFF preacher (deceased several years earlier) had sexually abused children. This case attracted wide attention in the media in Finland and Sweden when it became public in 2009. News coverage also suggested that this was not unfamiliar in Laestadian groups, and pointed to the tradition of confession and forgiving of sins in the Laestadian tradition, suggesting that this confessional praxis could also cover serious crimes. In response, the LFF central board published a statement on the website explicitly condemning all criminal acts, and especially abuse of children. It also emphasized that it is job of the police and the legal system to investigate and indict such crimes. The website thus made it possible 
for the LFF to make a clear statement in a medium directed not only to the LFF's own followers, but also to an outside audience. A slightly differently worded statement was also printed in the LFF's monthly bulletin, Sions missionstidning (2/2010), signed by chairman of the local congregation in Jakobstad. While the statement on the website was in the genre of a press release directed towards outsiders, the version in the bulletin was in a different wording and directed towards insiders. It is in fact a distinctive feature of the LFF website that it is the Laestadian website which is most frequently updated, and functions as a channel for news (information about internal seminars, courses etc.) significantly more than the other Laestadian websites do.

The Norwegian Lyngen-group's website was primarily established as a part of their youth work. The name of the website (samlinga.net) was proposed by young members, using the nickname (Norwegian samlinga 'gathering') of the group's assemblies (Olsen 2008, 30). This is the only website which seems to be directed specifically towards young people and youth work; it contains general information about assemblies and youth gatherings, and extensive pictures from weekend trips for young people. There is no radio material, but a guestbook and a closed discussion forum. One might say that the Lyngen group is directing the website towards its young members, and the monthly bulletin at an older audience.

\section{Debate Forums}

Debate forums provide an opportunity for researchers to join in internal discussions within the Laestadian tradition. A more extensive use of websites, especially streaming and podcasts, also indicates a process of individualisation. In the Laestadian tradition, the importance of attending assemblies to hear 'the spoken word of God' has traditionally emphasised the collective. 'The spoken word of God' in the gatherings has also been related to the presence of the Holy Spirit. The importance of gatherings is thus based on a theology which also relates to a social dimension, which is further evident in the tradition of forgiving of sins within the social group at the gathering. 'The spoken word of God' leads listeners to acknowledge themselves as sinners. During the gathering, the forgiving of sins can be given by a fellow Christian in the congregation. Because of streaming and podcasts of services, however, followers now can choose when to listen to a service, and they can choose to stop listening if they don't like what they hear. In this way, the possibility of a 'pull' dimension of the website becomes 
apparent. However, since web-relayed services do not offer the possibility of direct interaction, forgiveness of sin cannot be performed online.

The websites of Rauhan Sana and the Lyngen group have debate forums and guest books, which suggest adaptation to a younger audience. Participation in forums requires registration and a log-on ID. The Rauhan Sana forum is open for visitors, but registration is required to post comments. The Lyngen group forum was initially open, but as it turned out this was not without problems, which might shed some light on the fact that other Laestadian websites do not offer such opportunities. Debate forums raise the question of censorship and what are acceptable expressions. Requiring a log-in means that these forums primarily contain statements from insiders. During its first years, the guestbook and the forum on the Lyngen group's website was much visited and discussions were intense. After a few adjustments in layout and technical solutions, the forum and guestbook were completely removed in October 2006, as a result of a comment in the forum where a young member criticised the fact that one of the preachers - a businessman accused of fraud and under police investigation - used an assembly to read a letter to the congregation claiming his innocence (Olsen 2008,31 ). The next day, this critical comment from the young man was deleted from the forum, and the log-on requirement imposed; the discussion was terminated, and the forum and the guestbook were subsequently closed and deleted. In November 2009, after being closed for about two years, the forum and guestbook were re-opened, with an initiative for theological discussion on 'living vs. dead faith' - an initiative presumably approved by the preachers and considered appropriate for discussion among the younger members. Two months after the initiative had been launched, no comments had been added, and the forum was later closed again.

In the Rauhan Sana site forum, most posts are found in a room for general discussion on all topics, with over 480 written posts and over 7000 visitors (in February 2012). The youth forum is also quite heavily used, with almost 150 written posts and over 2000 visitors. There is also a separate area for comments relating to the Rauhan Sana bulletin; however, this only had three written posts, and had been read by only five people - perhaps simply because the audience who use the website read the printed bulletin to a very limited extent. Overall, however, the number of visitors and numerous discussion forums on the Rauhan Sana website clearly show that this website has become an important communication platform.

The use of debate forums on the Rauhan Sana and Lyngen websites represents a striking new development in a movement where loyalty to 
tradition and preacher authority is important. Followers now seem to be more liberated in expressing opinions on a wide range of topics, and these website discussion forums demonstrate increasing polyphony within the group. Moreover, one might assume that debate forums are still in an early stage of development, and might affect offline activities.

\section{Attitudes towards the Internet - Ambivalence and Restraint}

Within the different Laestadian groups, an ambivalence can clearly be seen towards new technology and the internet. This ambivalence is not explicit on the websites themselves, but occurs relatively frequently in the monthly bulletins and in sermons. A noticeable exception is the FAQ section on the Finnish Firstborn's website, where questions of intention and purpose of the website are explicitly addressed ('Mikä on kuuntelupalvelun ja verkkosivuston päämäärä?' ['What is the purpose and goal of a listening service and a website?']). As the answer makes clear, 'This site is not inventing anything new, but transmits existing knowledge' ('Tällä sivustolla ei keksitä mitään uutta vaan välitetään jo olemassa olevaa tietoa' $)^{4}$

Despite this now well-established use of websites by Laestadian organizations, warnings expressing distrust of the internet are also relatively common. These warnings typically express fairly standard conservative Evangelical-Christian views. A good example is the ambivalence towards computers and the internet that pervades a text published in the LFF's bulletin Sions missionstidning (SM 2/2010) under the title 'En kristen dator' ('A Christian computer'):

Over the past twenty years, technological advances in the IT industry have very powerfully influenced our society. For many people, the computer is an important tool, facilitating the flow of information in the workplace and providing us with the necessary facts in a few seconds by using Google. [...] This development is not only for the good, however. Involuntarily, my thoughts go to the tree of knowledge in the center of the Garden of Eden (Genesis 1,3). The tree of knowledge had both good and bad fruits, and God had forbidden our first parents to eat them. This prohibition was made, of course, out of love and care for humankind's best interests.

[...] We must nevertheless recall that the snake, the crafty enemy of the soul, does not leave us alone when we sit in front of our flashing computer

4 http://www.esikoislestadiolainen.fi/ukk.html (last visited 1st March 2012). FAQ - frequently asked questions. 
screens, but he has his snares everywhere, and is seeking to spread his evil fruits. (Sions missionstidning 2/2010, 5-6, my translation.) ${ }^{5}$

The analogy drawn in this article between the computer and the tree of knowledge rests on the argument that to covet knowledge may lead people into the arms of the Devil. Warnings are especially directed to men about websites containing violence and pornography. Children are also understood as especially vulnerable to the internet. Yet the article also acknowledges the benefits of computers and the internet for 'God's children' and for 'the work of God': in particular, how the internet can be used to maintain contacts with family, friends and fellow Christians. The potential for disseminating sermons feeds and podcasts, and for spreading information, are also regarded as positive and important.

This ambivalence regarding the internet, however, has led to different strategies being adopted by the various Laestadian groups. The comment quoted above comes from the LFF group, which is one of the groups now making use of the internet on a large scale; but even as the perceived benefits lead more and more Laestadian groups to turn to the internet as a means to communicate their beliefs, hesitation and warnings about the internet still persist. The computer needs be kept as a 'Christian computer', as it is put in the article from LFF's Sions missionstidning.

Thus, alongside the prevalent attitude in most religious groups, and increasingly also among Laestadian groups, that the internet is simply treated as useful technology (Campbell 2010, 26), which helps to support social practises and work-related tasks valuable for the religious community, IT is also seen as problematic in creating opportunities for deception and sin. 'In the hands of the Devil', it is a technology which can lead Christians onto a path of anti-Christian values. This is then paralleled by a conceptualization of the internet community as inauthentic or incomplete. All Laestadian groups place great importance on the spoken word of God at the assemblies:

5 Under de senaste tjugo åren har de tekniska framstegen inom IT-branchen påverkat vårt samhälle med en oerhört kraft. Datorn är ett viktigt arbetsredskap för många människor, något som underlättar informationsflödet på arbetsplatserna och förser oss med behövlig fakta efter några sekunders googlande. [...] Denna utveckling är dock inte enbart på gott. Osökt går mina tankar till Kunskapens träd, som stod mitt $i$ Edens lustgård (1 Mos. 3). Kunskapens träd hade både goda och dåliga frukter och Gud hade förbjudet våra första föräldrar att äta av dessa. Dette förbud var givetvis av kärlek och omsorg om människornas bästa. [...]

Vi måsta likväl säga att ormen, den listiga själafienden, inte lämnar oss ifred när vi sitter framför våra blinkande dataskärmar, utan han har ut sina snaror överallt. Han vill sprida sina onda frukter. (Sions missionstidning 2/2010, 5-6.) 
it is here, within the congregation, through the spoken word of God, that the Holy Spirit is understood as being present. Most Laestadian groups seem reluctant to concede that the Holy Spirit could also be present on the internet in the same way as in the spoken word at their gatherings. However, the streaming services on the websites to the Finnish Eastern-tradition groups (especially the LFF, Rauhan Sana, SRK and Elämän sana) suggest a shift on this issue.

\section{eLaestadianism?}

In terms of the distinction proposed by Helland in 2000, these Laestadian websites seem to constitute religion-online rather than online-religion. Traditional forms of religion and religious practices are imported into an online environment. The content on these websites is largely similar to the groups' printed monthly bulletins, mainly consisting of excerpts from devotional literature and information about gatherings and youth work, as well as some historical background about the group. This general survey of Laestadian websites shows that they are primarily used as tools for self-representation and to spread information to followers. Despite the fact that websites are a typical example of 'pull' media (Hoover 2008, 32-3), these Laestadian websites seem to be intended as controlled 'push' media, providing information and motivating approved behaviours.

The freedom which the use of online tools offers to community members for engagement with and even interpretation of texts poses new questions for religious communities such as the Laestadians (Campbell 2010, 40). Karaflogka $(2006,21)$ introduces the term e-religion to characterise how perceptions of and attitudes toward religion are affected by the polymorphic composition of new technologies. Analogously to Karaflogka's concept, one might propose the term eLaestadianism, much as Bunt (2009) has applied the term iMuslims to characterise how some Muslim groups use the internet.

With its social base in a rural environment and extending over a wide geographic area, it might be expected that the internet could provide a welcome technological tool for the Laestadian groups, especially for those groups which are transnational. Like radio, the new information technology could provide an opportunity for lay preachers to reach followers who are prevented from attending weekly gatherings. Similarly, there are examples of Facebook groups being set up by Laestadians, though the restricted access to these makes them difficult to monitor (cf. Olsen 2008, 32). At the present time, in 2012, however, despite the discussion forums and radio streaming 
of sermons on some of the websites, one cannot say that an eLaestadianism or online-Laestadianism is emerging.

\section{Websites - Reshaping the Offline Laestadian Community?}

Despite persisting ambivalence towards internet technology, the use of websites seems to have become fairly consolidated among many of the Laestadian groups. It remains to be seen whether in time the websites will replace the monthly bulletins. As is the case with the printed bulletins, the greatest reticence seems to be found among the Firstborn groups in Sweden and Norway, notwithstanding their production of historical booklets, brochures and newspaper announcements.

In the long run, it seems likely that the increasing use of the internet will also begin to affect other activities offline. Despite the attempts to run the websites as a 'push' medium, with a focus on the 'push' function of devotional literature and sermons, the new media inescapably provides opportunities for individuals to 'pull' out what they want. The interactive nature of the new technology and digital media will inevitably promote a situation where audiences are not merely passive and reactive observers, as they have been with the traditional texts.

To map the potential emergence of such changes in the offline Laestadian community, it will be necessary to carry out in-depth netnography within each group separately, and on a significantly greater scale than presented in this article. In 2012, the Laestadian use of websites and the internet as communication technology is still in its early stages, but the initial scepticism now seems to be abating. Occasional warnings against the new technology still recur in bulletins and sermons, but most Laestadians nowadays have access to a computer, either at home or at work, and will presumably also be becoming more comfortable with its use in the religious sphere. Nonetheless, it may well also happen that some groups could become more closed, in order to preserve their congregations from evil influences from 'the world'.

The warnings can to some extent also be explained by the gap between generations. One might expect that new generations, who have grown up with computers, the internet and social media, will have a completely different attitude to the new technology.

Another question is to what extent the use of websites and new technology in general may affect the authority of the Laestadian lay preachers. In the last few years, focus has been laid on the impact of the new technology on patterns of authority (cf. Campbell 2007; Hoover 2008). This is as yet an 
open question, however, regarding Laestadian lay preachers. It is also at present unclear in what way or to what extent preachers are involved in the production and editing of Laestadian websites, and investigating such questions would require detailed knowledge of each group, through research methods other than the online participant observation underlying this article.

Mastering communication strategies is typically a key issue in conserving authority, and the patterns of use and control of the new technology and the internet will therefore be of great importance for authority structures in the Laestadian movement in the years to come.

\section{Concluding Remarks}

The internet is clearly perceived within the Laestadian groups as a doubleedged sword. While it undoubtedly provides opportunities for posting and disseminating information about gatherings, mission trips, youth work, and for the distribution of devotional texts, there is an entrenched suspicion of the potential dangers of anti-Christian values inherent in technological advances such as the internet. Hence, the use of the internet and websites within the Laestadian movement is still in 2012 at an early stage, and it is too early to speak about online-Laestadianism or eLaestadianism.

\section{Bibliography}

\section{Anderzèn, Sölve}

2009 En 'väckeröst'. Tidskriften Ens Ropandes Röst i Öknen 1852-1854. - Anders Persson \& Daniel Lindmark (eds), Från Sara Greta till Lilla Svarta Sara. Väckelsen i litteraturen och väckelsens litteratur, 162-97. Malmö: Artos \& Norma bokförlag.

\section{Andreassen, Bengt-Ove}

2011 History as Religious Self-mediation. The Case of the Firstborn Laestadians. - Acta Borealia 28 (1), 1-18.

\section{Bird, Frederick \& Laurie Lamoureux Scholes}

2011 Research Ethics. - Michael Stausberg \& Steven Engler (eds), The Routledge Handbook of Research Methods in the Study of Religion, 81-105. London: Routledge.

\section{Bunt, Gary R.}

2009 iMuslims: Rewiring the House of Islam. Chapel Hill, N.C.: University of North Carolina Press. 


\section{Campbell, Heidi}

2007 Who's got the Power? Religious Authority and the Internet. - Journal of Computer-Mediated Communication, 12 (3), article 14.

2010 When Religion meets New Media. London: Routledge.

2011 The internet and Religion. - Robert Burnett, Mia Consalvo \& Charles Ess (eds), The Handbook of Internet Studies, 232-50. Chichester: Blackwell Publishing.

Cowen, Douglas E.

2011 The Internet. - Michael Stausberg \& Steven Engler (eds), The Routledge Handbook of Research Methods in the Study of Religion, 459-73. London: Routledge.

\section{Dawson, Lorne}

2000 Researching Religion in Cyberspace: Studying Religion on the Web. Jeffrey K. Hadden \& Douglas E. Cowen (eds), Religion on the Internet: Research Prospects and Promises, 25-54. New York: JAI Press.

\section{Helland, Chris}

2000 Online-religion/Religion-online and Virtual Communitas. - Jeffrey K. Hadden \& Douglas E. Cowen (eds), Religion on the Internet: Research Prospects and Promises, 205-23. New York: JAI Press.

2005 Online Religion as Lived Religion. Methodological Issues in the Study of Religious Participation on the Internet. - Online - Heidelberg Journal of Religions on the internet 1 (1), 1-16.

\section{Hepokoski, Warren $\mathbf{H}$.}

2000 The Laestadian Movement: Disputes and Divisions 1861-2000. Culpeper: W. H. Hepokoski.

\section{Hofmeyer, Isabel}

2008 Text. - David Morgan (ed.), Key Words in Religion, Media and Culture, 198-208. New York \& London: Routledge.

\section{Hokka, Leena}

2006 Suomen esikoislestadiolaisten ja Ruotsin äitiseurakunnan suhteen rakentuminen Rauhan Side -lehdessä. - Ingvar Dahlbacka \& Andrè Swanström (eds), Växelverkan och identitet. Kyrka och religion i Finland och Sverige 1809-1999, 173-204. Åbo: Kyrkohistoriska arkivet vid Åbo Akademi.

\section{Hoover, Stewart M.}

2005 Media. - Helen Rose Ebaugh (ed.), Handbook of Religion and Social Institutions, 305-19. New York: Springer.

2006 Religion in the Media Age. London \& New York: Routledge.

2008 Audience. - David Morgan (ed.), Key Words in Religion, Media and Culture, 31-43. New York \& London: Routledge. 


\section{Hoover, Stewart M. \& Monica M. Emerich}

2011 Introduction: Media, Spiritualities and Social Change. - Stewart M. Hoover \& Monica M. Emerich (eds), Media, Spiritualities and Social Change, 1-12. London \& New York: Continuum.

\section{Hosseini, Seyyed Hassan}

2008 Religion and Media, Religious Media, or Media Religion: Theoretical Studies. - Journal of Media and Religion 7 (1), 56-69.

\section{Højsgaard, Morten T. \& Margit Waarburg}

2005 Introduction: waves of research. - Morten T. Højsgaard \& Margit Waarburg (eds), Religion and Cyberspace, 1-11. New York: Routledge.

\section{Karaflogka, Anastasia}

2006 E-religion: A Critical Appraisal of Religious Discourse on the World Wide Web. London: Equinox.

\section{Kozinets, Robert V.}

2010 Netnography. Doing Ethnographic research online. London: Sage.

\section{Laney, Michael J.}

2005 Christian Web Usage: Motives and Desires. - Morten T. Højsgaard \& Margit Waarburg (eds), Religion and Cyberspace, 166-79. New York: Routledge.

\section{Mack, Burton L.}

2000 Social formation. - Willi Braun \& Russell T. McCutcheon (eds), Guide to the Study of Religion, 283-96. London \& New York: Cassell.

\section{Markham, Annette N.}

2004 The internet Communcation as a Tool for Qualitative Research. - David Silverman (ed.), Qualitative Research: Theory, Methods, and Practice, 95-124. London: Sage.

\section{Morgan, David}

2008 Introduction. Religion, media, culture: the shape of the field. - David Morgan (ed.), Key Words in Religion, Media and Culture, 1-19. New York \& London: Routledge.

\section{Nordvik, Torgeir}

2013 Protestbevegelse eller nytt kirkesamfunn? De Førstefødte læstadianere tar sakramentene i egne hender. - Din. Tidsskrift for religion og kultur (in press).

\section{Olsen, Torjer A.}

2008 Kall, skaperordning og makt. En analyse av kjønn i lyngenlæstadianismen. Ph.D. thesis. Tromsø: University of Tromsø. 


\section{Raittila, Pekka}

1967 Lestadiolaisuuden matrikkeli ja bibliografia. Helsinki: Suomen Kirkkohistoriallinen Seura.

\section{Stolow, Jeremy}

2005 Religion and/as Media. - Theory, Culture \& Society 22 (4), 119-45.

\section{Talonen, Jouko}

2001a Laestadianismen in an International Perspective. - HiF-Rapport 2001:6 Læstadius $200 \stackrel{\circ}{a}$, 53-9. Alta: Høgskolen i Finnmark.

2001b Laestadianismen i Finland. - HiF-Rapport 2001:6 Læstadius 200 år, 37-51. Alta: Høgskolen i Finnmark.

2005 Laestadianism/Apostolic Lutheranism in North America today. - Aila Foltz \& Miriam Yliniemi (eds), A Godly Heritage. Historical View of the Laestadian Revival and Development of the Apostolic Lutheran Church in America, 195-210. Frazee: The Authors. 